\title{
Study on Interest Rate Liberalization Impact on Commercial Bank Risks
}

\author{
J. Xiao, M. Z. Zhou \\ School of Economics and Management \\ Hubei University of Automotive Technology \\ Hubei, China.
}

\begin{abstract}
Compared with the controls, the Liberalization will totally change the ways to decide interest rates. The liberalization of interest rate system entitles the commercial banks to price capital independently as well as bring them to face the challenge of a series of interest rate risk in their operating, which makes the world positively commit to promoting the interest rate risk management system. The article is to analyze the significant influence of the reform of liberalization of interest rates on the rate risk of commercial banks and illustrate the measures to enforce interest rates management of commercial banks.
\end{abstract}

Keywords-interest rates liberalization; commercial banks; interest rate risk; deposit and loan interest rates

\section{INTRODUCTION}

The interest rate liberalization is one of the core content of the deepening financial reform. Full interest rate market mechanism can better stimulate the vitality of financial markets, the financial resources to make more optimal configuration. Under the premise of economic growth slowed to vigorously improve financial market mechanisms, financial institutions will have an impact, especially commercial banks. Commercial banks must confront rational and risk-averse to succeed through the test of reform.

\section{THE INTEREST RATE LIBERALIZATION AND INTEREST RATE RISK}

Interest rate liberalization is currently one of China's financial reform breakthrough points. Traced the course of the past, the central bank-led systematic interest rate reform began in the 1990s. Since the mid-1990s, Interest rate liberalization reform achieved successfully a breakthrough in four areas. (I) Release the inter-bank offered rate. LIBOR is often used as the benchmark interest rate, which reflects the supply and demand situation sensitive in money market. People's Bank of China released on the inter-bank offered rate control on June 1, 1996. The two sides decided to completely customize their lending interest rates based on supply and demand of funds. Since reform of interest rates liberalization has taken groundbreaking steps. (II Achieve interest rate liberalization of inter-bank bond. Our exchange bond market achieved market-oriented interest rate of treasury bonds through a variety of ways, such as interest rate tender in 1996. People's Bank of China to establish the national inter-bank bond market in June 1997. Bonds held by deposit-taking financial institutions circulate into the unified inter-bank bond market, while achieving interest rate liberalization of treasury bonds trading. China Development Bank successfully issued policy bank financial bonds by interest rate tender in the inter-bank bond market in September 1998. Ministry of Finance restarted the bond issue in the interbank bond market by market-oriented approach in 1999. So far, China's inter-bank bond market fully realized the interest rate liberalization of treasury bonds and financial bonds. (III)Reduce the scope of deposit and lending rates. In accordance with the guidance of a gradual reform, People's Bank of China has liberalized the foreign currency in addition to individual term foreign currency rates, and gradually liberalized the RMB deposit interest rate floor and RMB loan ceiling. People's Bank of China has launched a pilot project to release RMB agreement deposit interest rate. Since 2000, People's Bank of China has implemented the reforms mentioned above to achieve financial interbank deposit interest rate liberalization. Practice has proved that independent pricing and pricing capability of financial institutions has been significantly improved. IV) Foster money market benchmark interest rate. Benchmark interest rate market is the core of the formation mechanism. Shanghai Interbank Offered Rate and money market development has formed a pattern of positive interaction, and has been widely used in the market price of the product. [1]

China's commercial bank has a single asset and liability structure. To deposit and loan business oriented and the two do not match, the interest income is the main income of China's banking sector (see Table 1). The main bank's business is deposit and loan, and the two do not match. Deposits and loans of commercial banks are the main liabilities and assets. Time deposits and short-term loans accounted for the major proportion. Interest rate sensitive assets are greater than the interest rate sensitive liabilities. Net interest income will reduced be accompanied by falling interest rates. As can be seen from Figure 1, China's commercial banks' average capital adequacy ratio was $6.01 \%$ from 2007 to 2012, the average interest rate for deposits and loans was 3.01\%.Compared to the same period US commercial banks' average capital adequacy ratio is $11.5 \%$, a big gap between China and the US commercial banks. China's commercial banks should refer to the Basel Core Principles interest rate management, and actively promote the interest rate risk management system. With the advance of China's market-oriented reform of interest rates, should really give the commercial bank deposit and loan pricing autonomy to further refine the deposit and loan spreads, allowing commercial banks to directly bear the risk of interest rate fluctuations on revenues caused and to strengthen prevention and control. Thus avoid interest rate risk has important significance for China's commercial banks. 
TABLE I. CHINESE COMMERCIAL BANK INTEREST PROPORTION OF TOTAL REVENUE UNIT:\%

\begin{tabular}{c|c|c|c}
\hline BANK & $\mathbf{2 0 1 1}$ & $\mathbf{2 0 1 2}$ & $\mathbf{2 0 1 3}$ \\
\hline ICBC & 76.3 & 77.8 & 75.2 \\
\hline CCB & 76.7 & 76.7 & 76.6 \\
\hline ABC & 81.3 & 81.0 & 81.3 \\
\hline Bank of China & 69.5 & 70.2 & 69.6 \\
\hline $\begin{array}{c}\text { Bank of } \\
\text { Communications }\end{array}$ & 80.8 & 81.5 & 79.5 \\
\hline CITIC Bank & 84.6 & 84.4 & 81.2 \\
\hline Minsheng Bank & 78.7 & 74.8 & 71.7 \\
\hline Everbright Bank & 85.6 & 83.9 & 77.9 \\
\hline
\end{tabular}

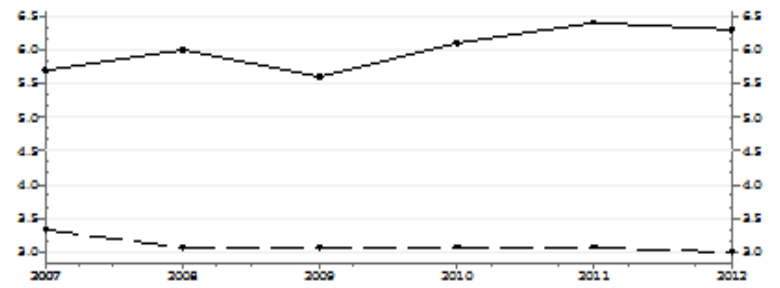

FIGURE I. CHINA'S COMMERCIAL BANKS' CAPITAL ADEQUACY RATIO AND DEPOSIT AND LOAN SPREADS (2007-2012)

\section{THE STATUS QUO OF CHINA'S COMMERCIAL BANKS AND THE TYPE OF INTEREST RATE RISKS MANAGEMENT ANALYSIS}

Interest rate risk is due to changes in interest rates and asset-liability duration mismatch losses caused net interest income to the possibility of commercial banks in a given period. Commercial banks asset-liability management is to manage interest rate risk become increasingly prominent. There are a lot of problems can not adapt to the market interest rate whether from internal management mechanism or external management environments. First, asset and liability management system of commercial banks still can not meet the interest rate risk management needs. For a long time due to the rigidities and distortions in the interest rate mechanism, the commercial banks lack of intrinsic motivation and sensitivity to interest rate risk management.[2] There are some banks have set up a special interest rate risk regulatory authorities, specifically for interest rate risk that may arise in their work. But because of its more decentralized and specialized functions is not strong and other factors, resulting in a lack of specialized functions for interest rate risk management, forming the overlap current situation with financial planning functions. Such as commercial bank interest rate management plan attached to the funds or the accounting department, mainly engaged in interest rates file transfer and interest rate policy implementation, interest rate risk management is almost a blank. Secondly, the outstanding problem of five state-owned commercial bank assets is the ratio of non-performing assets is too high, Agricultural Bank of China with the highest rate of non-performing assets. In essence, the non-performing assets of state-owned commercial banks, mainly due to payment of loans to state-owned enterprises with implicit subsidies nature caused. Commercial banks under the system of public ownership of Countries must give credit support aimed at maintaining the ability to pay the bank to make the Chinese public does not lose confidence in the bank. The most direct means of the bank after interest rate liberalization is to raise interest rates to attract deposits from customers. Commercial banks lack of effective mechanisms of self-restraint, central bank lack of strict supervision system, a substantial increase in deposit rates will inevitably encourage banks to obtain a higher return to compensate for the loss of revenue rising cost of deposits and risky investments in high-risk assets. This will inevitably lead to further growth of banks' bad assets, triggering a collapse risk. In the United States 1970-1986, 1977-1994 in Japan, respectively 16 and 17 years to complete the interest rate market, liberalization of deposit and lending rates which the United States has experienced six years of restrictions. In the early US interest rate market, commercial banks significantly increased the cost of funds, and savings and loan spreads narrowed inevitably suffer impact. Many commercial banks appear worsening business environment, the phenomenon of declining performance, the situation of small and medium banks collapse occurs. 1981--1991 years, the Bank of the United States highlights a serious problem, resulting in the loss of as much as $\$ 400$ billion. With the continuous progress of the interest rate market, increasing financial innovation, deepening financial markets, the US banking industry has taken response measures to change the unfavorable situation, adjust its business structure, increase the intermediary business development efforts, particularly to develop the asset management business. In the banks own transformation opportunity, the asset management business full advantage of resources. It has emerged as the mainstay of the intermediary business revenue sources. Asset management business has been rapidly expanding. The following 1990s is the United States golden age of mergers and acquisitions of commercial banks. Thus, in the interest rate market the US banking industry is not only impacted by changes in the market and has not been weakened, but more profitable.[3] From the current situation of China's commercial banks operating investigation, interest rate risk mainly for the following four types after the interest rate liberalization.

\section{A. Income Risk}

Income risk is due to changes in the value of interest rate sensitive assets and interest-sensitive liabilities changed inconsistencies when interest rates fluctuate. These risks mainly due to the assets and liabilities structure of commercial banks is single and does not match the maturity structure of its assets and liabilities. For example, when the commercial banks to borrow short-term deposits and lending long-term fixed-rate loans, Because the liabilities generated before the assets, banks need to re-pricing, meaning the interest rate sensitive liabilities greater than the interest rate sensitivity of assets, banks in the "negative gap" state. Cash flow loans fixed within the period, deposits and financing costs paid with interest rate fluctuations and changes, if interest rates go up, the bank earnings and potential value will be reduced. The deposit and lending gap of the total assets in the structure of China's commercial banks is too big. As of the end of September 2014, the balance of deposits and loans of financial institutions reached 33 trillion Yuan. A lot of money backlog and bear the continued risk of interest rate adjustment. 


\section{B. Structural Risk}

The results of interest rates liberalization in developed countries show that the interest rate market will lead to savings and loan spreads narrowed, leading to a net interest margin decreased risk. At the same time, savings and loan spreads volatility term structure mismatch will result in a net interest income decreased risk. China's commercial banks extensive long-term business model is likely to result in higher deposit rates rise above lending rates rise, increasing the risk structure.

\section{Embedded Option Risk}

Customer deposits or loan period will be decided according to fluctuations in interest rates, and thus advance repayment or loan. Due to the above behavior of customers, commercial banks will bear the consequent interest rate risk. This risk arises in the assets, liabilities and off-balance sheet portfolio of the bank's option selection. For example, when interest rates rise, depositors will withdraw their deposits, higher interest rates and then to deposit new deposits. When interest rates tend to fall, loan customers will get new loans at low interest rates prior to the early repayment of loans obtained in the period of high interest rates. In order to attract customers, commercial banks can not prevent their customers from the use of the rights.

\section{The Basic Point of Risk}

Bad operating status of commercial banks will lead to basis risk when the interest rate fluctuations. For example, unreasonable period between deposit and loan spreads, additional interest or high interest savings, unprincipled lower lending rates, resulting in deposit and loan spreads decreased or even a loss.

\section{COMMERCIAL BANKS' INTEREST RATE RISK MANAGEMENT STRATEGIES IN CHINA}

\section{A. Establish and Improve the Management Center of Interest Rate Risk}

Western commercial banks with specialized organizations that Asset Liability Management Committee (ALCO) to manage interest rate risk. China's commercial banks should set up a special interest rate risk management, increase $R \& D$ investment to interest rate risk management. On the one hand the establishment of interest rate forecasting agency, its main function is based on the country's macroeconomic situation, industry reforms and changes in domestic and foreign affairs to predict trends in the development of interest rates. On the other hand the establishment of the interest rate risk control mechanism, through risk control mechanism, we can always grasp the small and medium commercial bank interest rate risk, control of commercial bank losses caused by changes in interest rates, and through asset liability management, gap management and other methods to change the bank's assets liabilities to minimize their losses.[4]

\section{B. Establish a Rational Pricing Mechanism to Raise the Interest Rate Risk Management Capabilities}

State is no longer strict controls on interest rates after the interest rate market, allowing commercial banks to have some independent pricing of deposit and lending rates. Before the interest rate market, the domestic commercial banks can only perform relatively stable interest rates under control regime.
Commercial banks lack independent pricing and risk management and control capabilities, the price does not reflect the cost of capital and risk management of commercial banks, commercial banks making themselves lax internal management and risk control is ignored. At the same time this also distorts the dominant position of commercial banks as indirect financing market, resulting in most of the funds went to administrative inefficiency and medium-sized state-owned enterprises. After the interest rate market, the commercial banks for asset pricing and capital structure can be adjusted independently, truly "self-management, self-risk, self-financing, self-restraint."

\section{Change the Status of a Single Asset and Liability Structure through Financial Innovation}

Commercial banks should change simple, low-value-added business to more complex and higher value-added financial products. As a positive development assets can be realized emergency lending and investment products as well as bills to expand the business. In the modern interest system, interestbased financing for bill has a special role. The interest rates in this system has a high degree of correlation, it is a reflection of changes in market interest rates of the core indicators.

\section{Develop Intermediary Business and Personal Retail Business in Order to Achieve Diversification}

Traditional banking business assets decline in the relative position of social capital in circulation trend is irreversible. The share of banks from financial intermediation channels can also be seen shrinking traditional banking business, "financial disintermediation" increasingly evident. Commercial banks should speed does not depend on the spread of intermediate business and sheet business, rely on non-revenue growth spreads to compensate for declining revenues spreads.

\section{E. To Develop an Online Business}

With the rapid development of Internet technology, the development of online banking and related business by leaps and bounds. However, the development of the domestic electronic financial services is relatively lagging behind. Under the impetus of the interest rate liberalization and financial reform, commercial banks should strive to do with international standards, and constantly improve its online banking and online trading business to gain more market share and greater market share.

\section{REFERENCES}

[1] Jin LinLin \& Zhu YuanQian \&Ba ShuSong, International Experience and Implications of interest rate liberalization impact on commercial banks. Rural finance research,1(1),pp.53-57,2012.

[2] Wu FuLin, China to what extent the interest rate market. Economist,4(4),pp.70-76,2012.

[3] Hu XinZhi \& Yuan Jiang, China's interest rate market rational choice. International Economic Review,6(6),pp.132-145,2011.

[4] Zhong Jin, The interest rate market and interest rate risk management. Modern Economic Science, 6(6), pp. 28-30,2003. 